\title{
Behavior of major and minor elements in a temperate river estuary to the coastal sea
}

\author{
S. Patra · C. Q. Liu F. S. Wang S. L. Li • \\ B. L. Wang
}

Received: 14 April 2011/Revised: 21 June 2011/Accepted: 21 November 2011/Published online: 11 August 2012

(c) CEERS, IAU 2012

\begin{abstract}
Water samples were collected for 23 different stations along a cross section profile of an estuary extending over to adjacent sea. The collected water samples were filtered and analyzed for major-minor ions and strontium isotope using the standard procedure to understand the geochemical behaviors of major and minor elements. The normalized values indicated that all riverine elements were entering to adjacent coastal sea with some significant variations at the estuary. The seawater dilution and regression lines explain about the overall patterns for seven elements. Removal processes were detected on calcium, magnesium, strontium and sulfate in the estuarine region. No significant mineral precipitation observed to release magnesium with respect to calcium. Minor variations of strontium and sulfate ions could be attributed to the presence of organic matter in the study area. Comparing seven elements with total suspended matters revealed that the total suspended matters played crucial role in either
\end{abstract}

S. Patra · C. Q. Liu (凹) · F. S. Wang · S. L. Li · B. L. Wang

State Key Laboratory of Environmental Geochemistry,

Institute of Geochemistry, Chinese Academy of Sciences,

Guiyang 550002, People's Republic of China

e-mail: liucongqiang@vip.skleg.cn

S. Patra

Graduate School of Chinese Academy of Sciences,

Beijing 100039, People's Republic of China

Present Address:

S. Patra

Ministry of Earth Sciences, ICMAM Project Directorate,

Chennai, Tamil Nadu, India

F. S. Wang

Applied Radiation Institute, Shanghai University,

Shanghai 201800, People's Republic of China adsorption or absorption of all the elements in estuary before it reaches to coastal sea. Mixing patterns of strontium isotope showed minimal non-conservative with an evidence of active geochemical process in the estuary.

Keywords Adsorption and absorption - Changjiang river estuary - Major and minor elements - Strontium isotope . Total suspended matter

\section{Introduction}

Major and minor element concentrations are being used in the river and its drainage basin to understand the effect of weathering, erosion and anthropogenic process as a proxy because of high abundance in the earth crust. Rivers transport the major geochemical information from continents to ocean through estuary. Estuarine environments are an important part for the elemental cycles and also act as a marginal filter (Lisitsyn 1995), and regulate the amount of river-borne elements entering to the coastal environment and ultimately the deep ocean (Ramanathan et al. 1993). The estuaries dilute all types of dissolved and solid materials due to tidal influences over a period of residence time and generate green house gases through digenesis-autogenic process which affect the overall elemental compositions (BrichGF and Teutsch 1996). The estuarine turbidity zone (density driven circulation) interacts with these elements. Thus, the estuarine mixing and subsequent exchange with adjacent waters those are fundamental process governing biological, chemical and sediment interactions within coastal and estuarine system (Bell 1994).

If these ion constituents altered substantially in the estuarine region, it may not reflect the river elements transport flux precisely to the adjacent sea. 
This paper attempts to provide and quantify those altered processes made at Changjiang river estuary, the third largest river in the world (Wang et al. 2007). Numerous hydrology and biogeochemistry study had conducted and discussed (Hu et al. 1982; Zhang et al. 1990; Chen et al. 2002 Yang et al. 2002; Ding et al. 2004). In addition, turbidity distributions in relation with tidal fluctuations and export nature to coastal sea have been studied too (Zhou 1994; Zhang et al. 1995; Wang et al. 1995; Hu and Hu 1995; Shi and Ling 1999; Li et al. 2000a, b; Jiang and Yao 2002; Li and Zhang 2003). But the impact and influence of estuarine maximum turbidity to the behavior of major and minor elements have not been investigated. In this regard, an observation has been made during June 2005 to understand the geochemistry of major and minor elements, their variation and behavior during the transition from river to coastal sea.

\section{Materials and methods}

\section{Study area}

The Changjiang river originates in the Qinghai-Tibet Plateau and flows eastwards for $6,300 \mathrm{~km}$ and meets East China Sea, form a delta Chogming Island (Yi et al. 2003). The upper basin is characterized by complex rock compositions, including widely distributed Paleozoic carbonate rock in the south with an area of $400 \times 10^{3} \mathrm{~km}^{2}$ (about $20 \%$ of the total carbonate area in China); Jurassic red sandstone in the Sichuan Basin; and Mesozoic igneous rocks in the river source area. The middle-lower basin mostly consists of Paleozoic marine and quaternary fluviolacustrine sedimentary rocks, together with intermediate to felsic igneous rocks that are common but sporadic (Yang et al. 2004). The major part of the Changjiang basin is influenced by East Asian monsoon. Annual atmospheric precipitation ranges from less than $400 \mathrm{~mm}$ in the river source area to more than $2,000 \mathrm{~mm}$ in highlands of the middle-lower reaches, with an average of $1,100 \mathrm{~mm}$ (Yang et al. 2004).

The study area was selected at the lower reach of Changjiang river between Nanjing City and East China Sea (Fig. 1). The Huangpu River (station no. 7) passes through the Shanghai city and empties at the mouth. The Chongming Island divides the Changjiang river channel in the downstream area. The South branch downstream from the Liuhe is again divided in the North and South Channels by the Changxing and Hengsha Island, and finally the South Channel branches into the North and South passage downstream from Jiuduansha, thus the river has three points of bifurcation and four outlets before entering into the East China Sea (Wang and Liu 2003; Li et al. 2000a, b). The water mixes very forcefully in these long channels that lead to energetic resuspension of bottom sediments ( $\mathrm{Li}$ et al. 2000a, b).

Sample collection and analytical procedure

A total of 34 water samples were collected engaging a mechanized boat ( 23 surfaces and 11 bottoms) during June 2005 along the Changjiang river. The surface water samples were collected using a clean plastic bucket and bottom water samples were collected using 5-L Niskin bottle. Parameters like $\mathrm{pH}$, specific conductance $(\mathrm{Ec})$, total dissolved solids (TDS) and alkalinity $\left(\mathrm{HCO}_{3}\right)$ were measured on board soon after every sampling. The $\mathrm{pH}$ was measured with a calibrated portable mobile $\mathrm{pH}$-meter that had been calibrated (NBS 7 and NBS 10) at every 10 sample intervals. Specific conductance and TDS were measured using special HORIBA electrode. The $\mathrm{HCO}_{3}{ }^{-}$measurements were performed with a digital titrate on the $50 \mathrm{ml}$ of the collected sample using $0.01 \mathrm{M} \mathrm{HCl}$. Chlorinity $(\mathrm{Cl} \%)$ was measured by argentometric titration method in the shore
Fig. 1 Map of the sampling locations along the Changjiang river estuary from Nanjing City to East China Sea and the no. 7 represents the Huangpu River

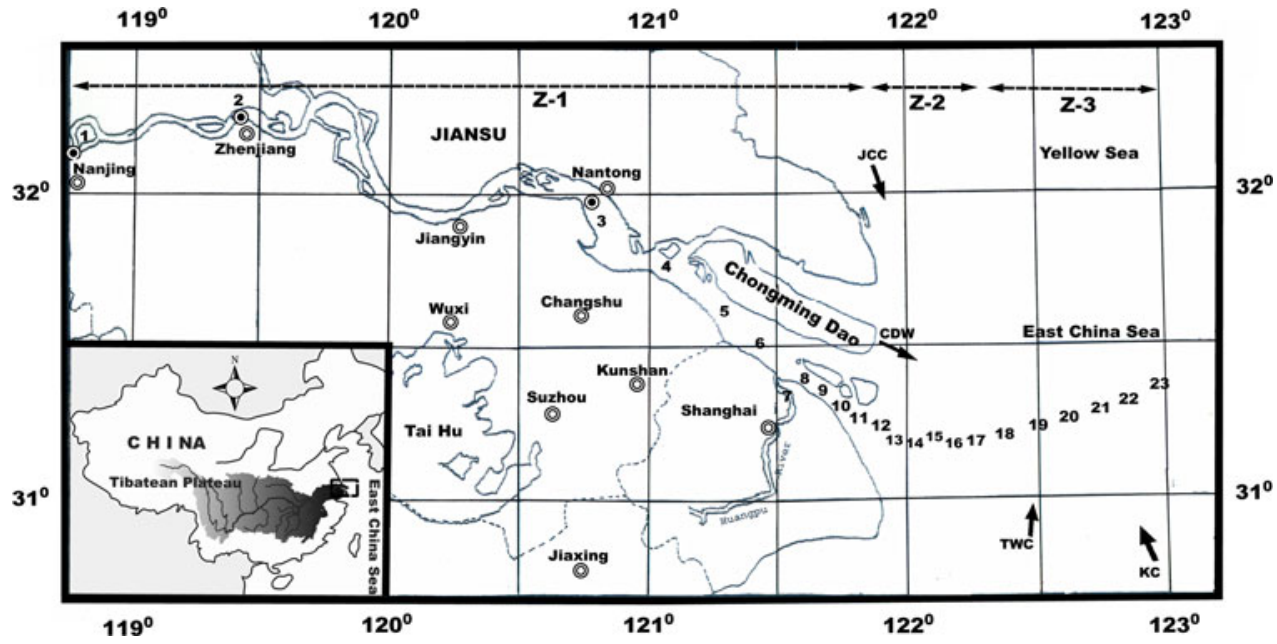


laboratory, and the silver nitrate solution $\left(\mathrm{AgNO}_{3}\right)$ was standardized with standard seawater of chlorinity $19.374 \%$ obtained from Copenhagen, Denmark. The salinity calculations were made after correction from Knudsen's table (Knudsen 1902).

About 11 of water samples filtered through pre-weighted acid-washed $0.45 \mu \mathrm{m}$ cellulose acetate filter paper (Millipore). The filtered paper was warped with aluminum foil and kept in Petri-dish for total suspended matter (TSM) calculations. The filtered water sample was split into various analytical purposes, $50 \mathrm{ml}$ of the filtered samples was stored separately in clean HDPE bottles for anion analysis, and another $50 \mathrm{ml}$ of the samples was acidified with ultrapurified $\mathrm{HNO}_{3}$ and stored in a clean HDPE bottle for cation measurements. Sufficient care was taken for the samples (i.e. collection, filtration and analysis) to avoid contamination and stored in a cool and dark place until analysis.

Cations were analyzed by inductively coupled plasmaoptical emission spectrometry (ICP-OES) and the anions were analyzed by ion chromatography (ICS-90, DIONEX). To separate dissolved strontium from major element in the water for measuring $\mathrm{Sr}$ isotopic composition, the filtered water samples were directed to pass through an AG50 W-50 resin column through $\mathrm{HCl}$ medium. All strontium isotope $\left({ }^{87} \mathrm{Sr} /{ }^{86} \mathrm{Sr}\right)$ compositions were measured using thermal ionization mass spectrometry (TIMS: GV Instruments) at the State Key Laboratory, Institute of Geochemistry, CAS, Guiyang. The value ${ }^{87} \mathrm{Sr} /{ }^{86} \mathrm{Sr}$ for NSB987 strontium standard was $0.710236 \pm 0.000012(n=6)$ during the period of sample measurement.

\section{Results and discussion}

General characteristics of the river

All stations chosen for sampling were divided into three Zones according to their salinity gradient. These are classified as Changjiang river downstream area (Stn. 1-11; Salinity $<0.1 \mathrm{psu}$ ), Changjiang river estuary (Stn. 12-16; Salinity 0.1-14 psu) and Coastal sea (Stn. 17-23; Salinity 15-32.3 psu). The results of the chemical and isotopic compositions are summarized in Table 1 . The $\mathrm{pH}$ varied from 7 to 8.7 with a nonsystematic variation from river to coastal sea. Mook and Koene (1975), Ramanathan et al. (1993) and Wang and Liu (2003) observed the unsystematic variations of $\mathrm{pH}$ in the river and coastal sea water mixing zone. The short-term variation of $\mathrm{pH}$ in the system was dominated by the carbonate equilibrium. As results of $\mathrm{pH}$, the estuary did not show any consistent transition between riverine and seawater mixing. The Ec and TDS results showed sharp increase due to mixing of river water with seawater. The increasing trend of Ec and TDS was consistent with previous observation in Changjiang estuary by Wang and Liu (2003) and also by Ramanathan et al. (1993) in Cauvery estuary, India. The TSM varied from 0.5 to $518.0(\mathrm{mg} / \mathrm{L})$ in the entire study stations. The maximum concentration of TSM observed in estuary region $(212 \mathrm{mg} /$ L). However, the concentrations of TSM decreased as salinity increases.

\section{Cation and anion}

The bicarbonate concentration increased with increase in salinity, due to river dilution with seawater (Table 1). The fluctuation in the estuarine regions may be due to the consumption processes. Sulfate $\left(\mathrm{SO}_{4}\right)$ showed conservative mixing with seawater. The higher concentration of $\mathrm{SO}_{4}$ in estuary and coastal sea could be due to the effect of remineralised organic matters (Schijf 2007) and also the consumption by local vegetation in the river area (Ramanathan et al. 1993). Whereas, the $\mathrm{SO}_{4}$ removal process compensated in the estuary by the contributions of the organic matters (Ramanathan et al. 1993).

All the major cations represented wide variations with respect to increase in salinity. Such types of behavior of the major elements are very similar to the observation in the Indian Subcontinent rivers (Ray et al. 1984; Subramanian and Jha 1988; Ramanathan et al. 1993; Sharma et al. 2007). Sodium (Na) was lower in concentrations because of its preferential absorption and incorporation onto silicates $\left(\mathrm{SiO}_{2}\right)$. Calcium $(\mathrm{Ca})$, magnesium $(\mathrm{Mg})$ and $\mathrm{Na}$ showed their concentrations closer to seawater dilution line in river region, indicating the fluvial contributions. The dissolved strontium ( $\mathrm{Sr}$ ) followed a mixing line by two end-member concentration salinity plots. Few scatters and several points fall above the mixing line in the estuary (5-salinity), but the rest of the samples showed for conservative nature. In the plots of ${ }^{87} \mathrm{Sr} /{ }^{86} \mathrm{Sr}$ isotope versus inverse $\mathrm{Sr}$ concentrations, an acceptable linear correlation exhibited for river and seawater mixing. The river end member has high ${ }^{87} \mathrm{Sr} /{ }^{86} \mathrm{Sr}$ values and coastal sea has lower ${ }^{87} \mathrm{Sr} /{ }^{86} \mathrm{Sr}$ values $\left(r^{2}=0.87\right)$. Though water samples have taken in the estuarine environment, it could be influenced by the diurnal mixing actions for short time period (Fig. 2).

\section{Elemental concentrations normalizing to seawater}

To avoid the dilution error and to visualize the data properly, all the cations (including $\mathrm{Sr}$ ) were normalized to $\mathrm{Na}$, and all anions were normalized to chlorine $(\mathrm{Cl})$. Schijf and Byrne (2007) reported that about 2-3\% uncertainty in the $\mathrm{Na}$ and $\mathrm{Cl}$ concentrations was caused due to analytical precision and represented actual salinity fluctuations due to annual changes in coastal waters or a minor, but variable degree of mixing between the spring and sewage effluents 


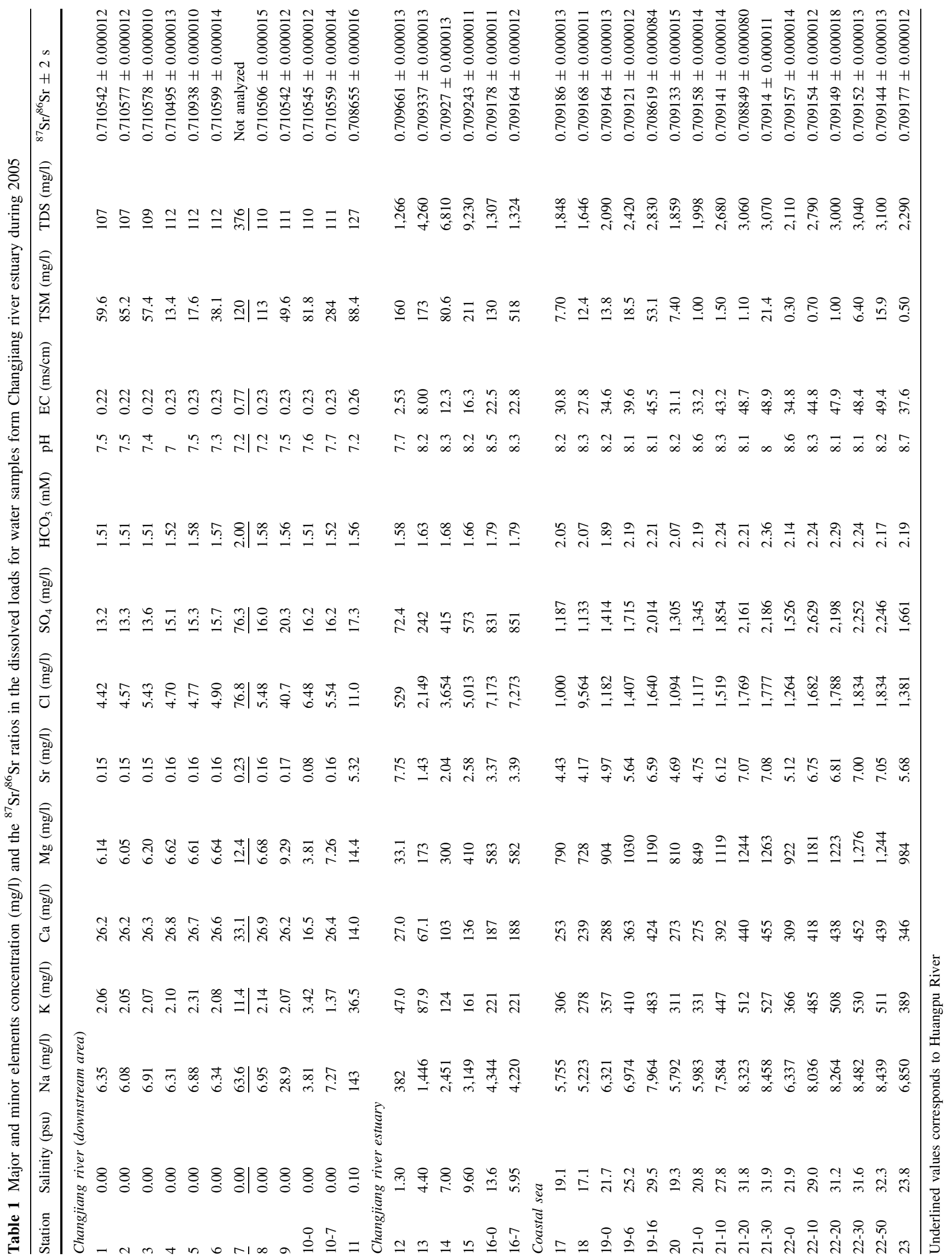




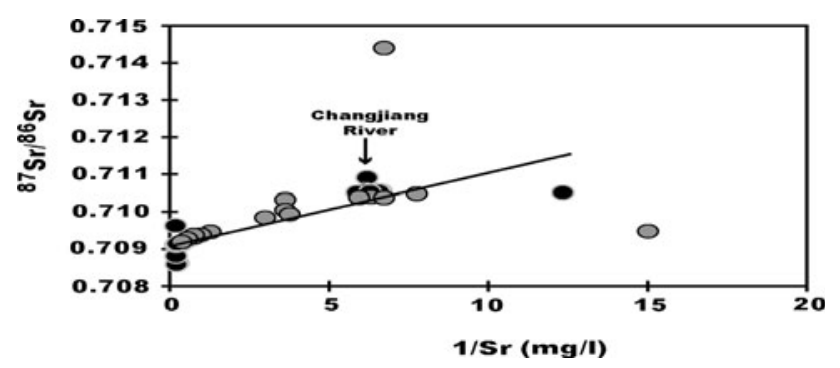

Fig. $2{ }^{87} \mathrm{Sr} /{ }^{86} \mathrm{Sr}$ versus $1 / \mathrm{Sr}(\mathrm{mg} / \mathrm{l})$ isotopic mixing ratios diagram with sea water for the dissolved load in the Changjiang river estuary. The gray solid circles are the open data study samples adopted from Wang et al. (2001) and Wang and Liu (2003)
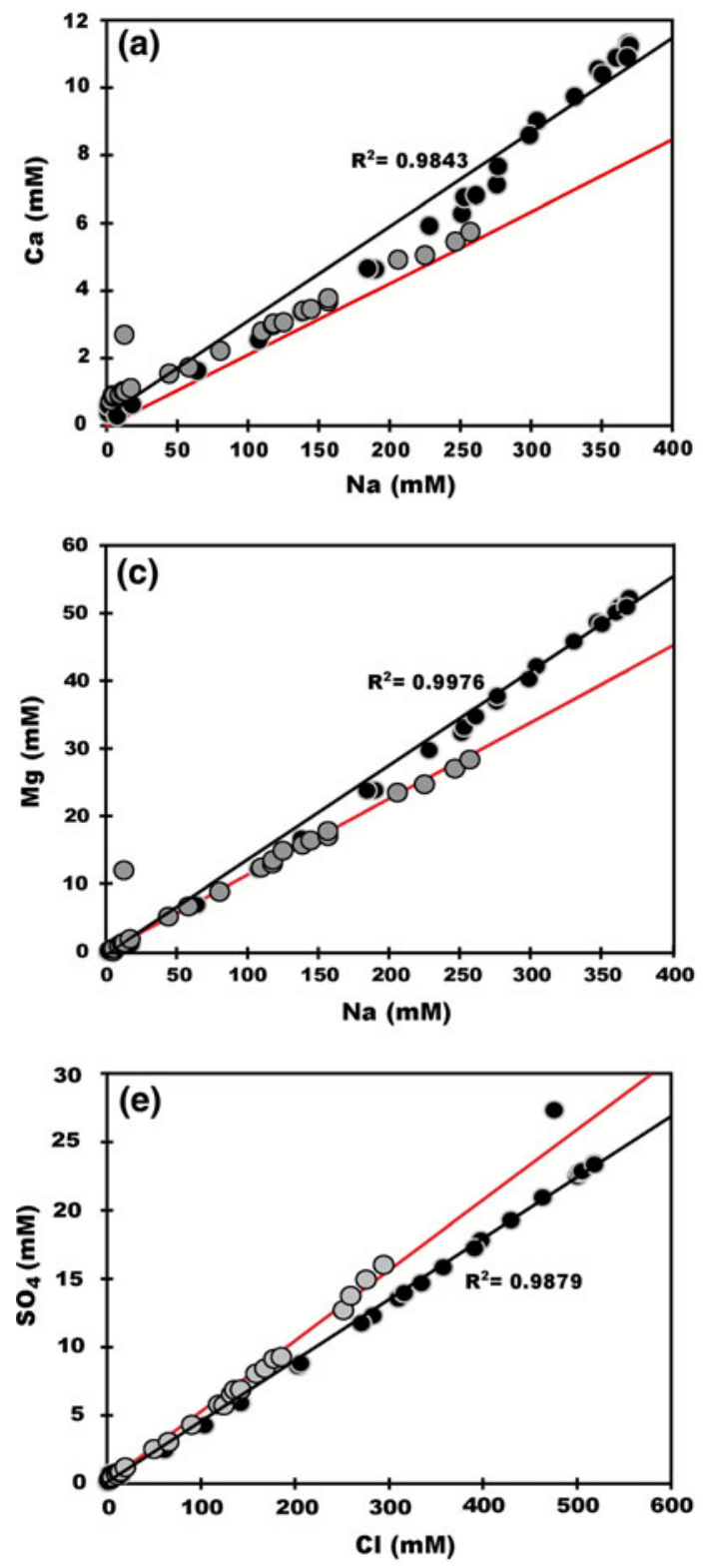

Fig. 3 Mixing plots a $\mathrm{Na}-\mathrm{Ca}, \mathbf{b} \mathrm{Na}-\mathrm{K}, \mathbf{c} \mathrm{Na}-\mathrm{Mg}$, d Na-Sr, e $\mathrm{SO}_{4}-$ $\mathrm{Cl}$, f Density versus $\mathrm{Na}-\mathrm{Cl}$ for the major and minor elements. The solid straight is the mixing line and the red straight line is the and ambient seawater, caused by tidal actions. Cation and anion are two separate groups, so errors arising from sample dilutions and instrument instability are always highly correlated within the each group.

Elemental behavior during mixing

The highly linear correlations of $\mathrm{Na}$ and $\mathrm{Cl}$ ions with density (Fig. 3f) indicated that $\mathrm{Na}$ and $\mathrm{Cl}$ behaved conservatively with respect to mixing with coastal sea water. It followed that a linear mixing plots of some other elements versus $\mathrm{Na}$ or $\mathrm{Cl}$ signify conservative behavior of that
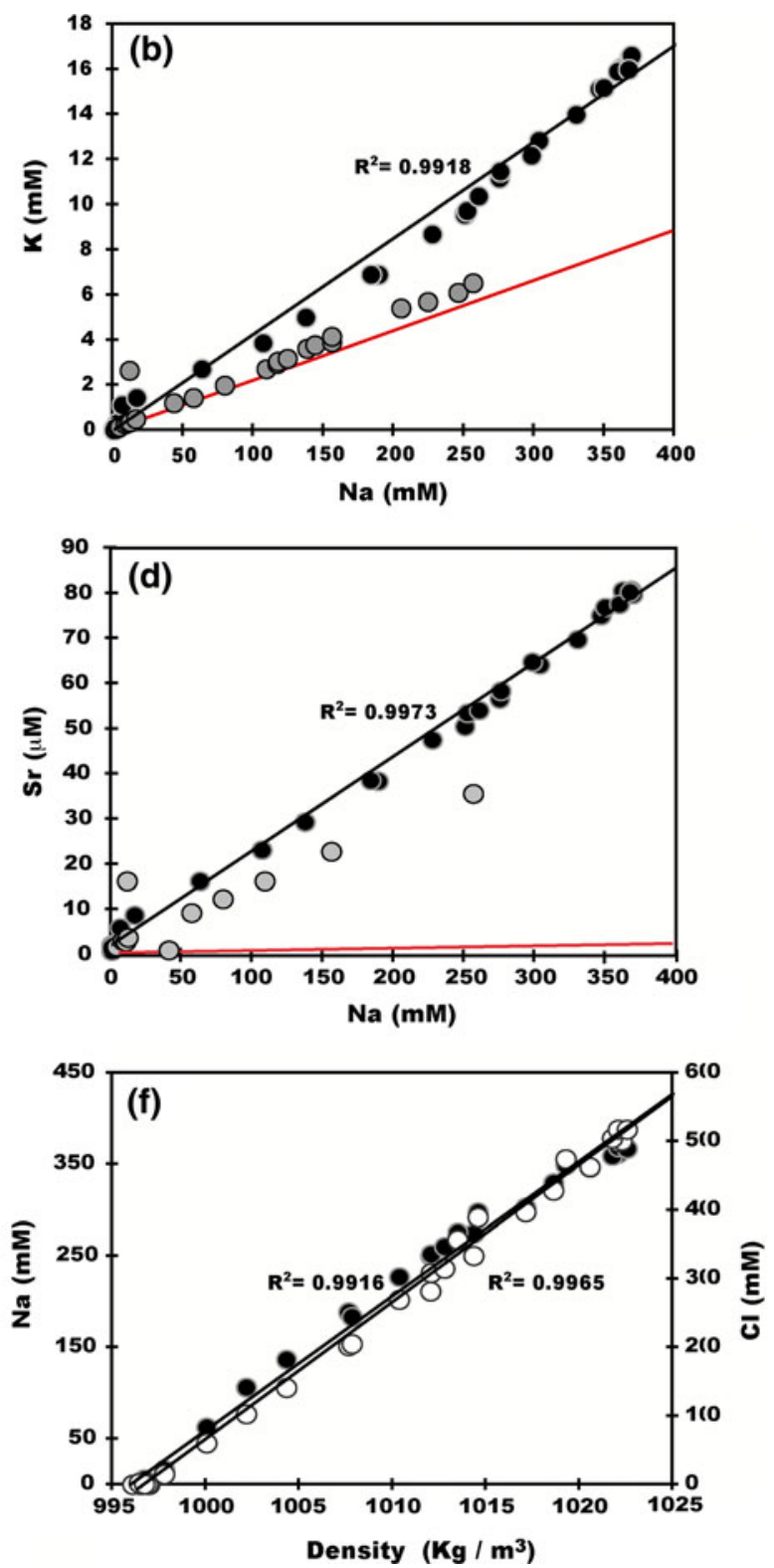

seawater dilution line. The black solid circles are our study samples and the gray solid circles are the open data study samples referred from Wang et al. (2001) and Wang and Liu (2003) 
elements, whereas positive or negative deviations from linearity must be caused due to the enrichment or release at the corresponding salinity. The mixing plots of $\mathrm{Na}-\mathrm{Ca}$, $\mathrm{Na}-\mathrm{K}, \mathrm{Na}-\mathrm{Mg}, \mathrm{Na}-\mathrm{Sr}$ and $\mathrm{SO}_{4}-\mathrm{Cl}$ indicated that the major cations were linearly mixing only in higher salinity, but overall represented conservative behavior (Fig. 3a-e). It also observed that all major and minor elements deviated from the seawater water slope line in the intermediate salinity region. The present study observation was quite similar with the observation made by Wang and Liu (2003). However, shift could be attributed to pollution or Suess Effect and the systematic differences of elements occurred could be due to water-mass residence time before entering to coastal sea.

It is noteworthy that the substantial removal of $\mathrm{Ca}, \mathrm{Sr}$ and $\mathrm{K}$ did not affect $\mathrm{Mg}$ concentrations in higher salinity, may likely to be removed of those elements due to distinct process effects. To understand the process, all the samples were normalized with standard seawater. Table 2 represents the average ionic ratio concentrations with respect to regions corresponding to standard seawater. These values were smaller or larger than one-indication depletion or enrichment of the numerator ion with respect to sea water, respectively. It showed that the river having higher values, 3-4 times more compared to estuary and coastal sea region. Comparing between estuary and coastal sea, it clearly prominent that coastal sea values were closer to standard seawater, but the values in river and estuary were higher than that of standard seawater. They showed linearity with other elements and also reported significant conservative behavior, whereas positive or negative deviations must be caused due to the enrichment or removal process at the corresponding salinity. Hunter (1983) proposed that, as the river water mix with seawater, the negative charge on suspended colloids is not reversed by adsorption of sea

Table 2 Major anion and cation ratios in Changjiang river, estuary and coastal seawaters with respect to ambient sea water (SW)

\begin{tabular}{lcll}
\hline Zone & River & \multicolumn{1}{c}{ Estuary } & Coastal sea \\
\hline \multicolumn{3}{l}{ Without normalized elemental ratio compositions (mM) } \\
$\mathrm{K} / \mathrm{Na}$ & 0.189 & 0.0381 & 0.0343 \\
$\mathrm{Ca} / \mathrm{Na}$ & 1.816 & 0.0278 & 0.0287 \\
$\mathrm{Mg} / \mathrm{Na}$ & 0.748 & 0.1155 & 0.1377 \\
$\mathrm{Sr} / \mathrm{Na}$ & 0.0057 & 0.00107 & 0.00021 \\
$\mathrm{SO}_{4} / \mathrm{Cl}$ & 0.9059 & 0.0437 & 0.0455 \\
$\mathrm{Standard}$ sea water normalized elemental ratio compositions \\
$\mathrm{K} / \mathrm{Na}$ (SW: 0. 0218) & 8.69 & 1.75 & 1.57 \\
$\mathrm{Ca} / \mathrm{Na}$ (SW: 0. 0219) & 82.96 & 1.27 & 1.31 \\
$\mathrm{Mg} / \mathrm{Na}$ (SW: 0. 1126) & 6.65 & 1.026 & 1.23 \\
$\mathrm{Sr} / \mathrm{Na}$ (SW: 0. 00091) & 31.0 & 6.00 & 1.10 \\
$\mathrm{SO} / \mathrm{Cl}$ (SW: 0. 0517) & 17.52 & 0.84 & 0.881 \\
\hline
\end{tabular}

Table 3 Correlation matrix of major and minor elements with total suspended matter (TSM)

\begin{tabular}{llll}
\hline & River & Estuary & Coastal sea \\
\hline TSM versus $\mathrm{Cl}$ & 0.09 & 0.49 & 0.14 \\
TSM versus $\mathrm{SO}_{4}$ & 0.17 & 0.50 & 0.07 \\
TSM versus $\mathrm{Na}$ & 0.06 & 0.43 & 0.16 \\
TSM versus $\mathrm{Mg}$ & 0.13 & 0.47 & 0.18 \\
TSM versus $\mathrm{Sr}$ & 0.04 & 0.47 & 0.15 \\
TSM versus $\mathrm{Ca}$ & 0.04 & 0.48 & 0.19 \\
TSM versus K & 0.04 & 0.48 & 0.17 \\
\hline
\end{tabular}

Table 4 Saturation state of Changjiang river, estuary and coastal sea with respect to various form of calcium carbonate

\begin{tabular}{lccc}
\hline Mineral & \multicolumn{3}{l}{} \\
\cline { 2 - 4 } & River & Estuary & Coastal sea \\
\hline Calcite & 0.34 & 0.52 & $\underline{1.32}$ \\
Aragonite & 0.16 & 0.28 & $\underline{1.12}$ \\
Dolomite & -0.84 & -0.85 & -0.83 \\
\hline
\end{tabular}

Saturation state $\Omega$ is the solubility product, where values larger and smaller than 1 represent super saturation and under saturation with respect to the corresponding mineral, respectively

Zone near or above saturation are underlined for emphasis

water cations, but remains uniformly negative throughout the entire salinity range, decreasing sharply in magnitude during the first few per mill salinity. This confirms that the adsorption process for positive ion particles on to suspended matters occurring continuously at lower salinity regions and the reaction may significantly pronounce in the estuary. And the suspended sediment concentration may reduce from estuary to sea through the principles of diffusive transport process. The mineral solubility had calculated for the three regions with respect to some common elements in the system namely, aragonite and calcite (with or without $\mathrm{Mg}$ ). Saturation state of dolomite was also determined. The solubility product data have taken from the literatures. Nevertheless, both river and estuary have oversaturated, ascertain that removal processes are the major dominant process (Tables 3, 4).

$\mathrm{Sr}$ isotopes along the salinity gradients

Past studies in estuary on $\mathrm{Sr}$ behavior revealed two component conservative mixing between sea and river water (Andersson et al. 1992; Ingram and Sloan 1992; Brunskill et al. 2003; Sharma et al. 2007). Recent data on groundwater mixing with seawater in a subterranean estuary indicated that $\mathrm{Sr}$ can behave non-conservatively under certain redox conditions (Charette and Sholkovitz 2006). That $\mathrm{Sr}$ isotope along salinity gradients was not affected by precipitation and desorption from estuarine sediments and 
thus behaved conservatively observed for the San Francisco Bay (Ingram and Sloan 1992; Ingram and DePaolo, 1993) and for the Baltic Sea (Andersson et al. 1992). On the contrary, in the present study, the $\mathrm{Sr}$ in Changjiang river with coastal sea is generally represented in a conservative manner (Fig. 3) and the minimal deviation is observed from the pure conservative line. These deviations may be accepted due to biological or microbial process in the estuary. Xu and Marcantonio (2007) reported that the Sr has three sources in the Mississippi River mixing zone. Apart from river and sea, the third source could be from (1) submarine ground water discharge, (2) radiogenic particulate $\mathrm{Sr}$ that is dissolved and released into the mixing zone and (3) may be the greater concentration of radiogenic colloidal organic and/or inorganic particles. The Sr suspended load for Changjiang river estuary has about 0.015 fold higher than the dissolved load in river zone reported by Wang et al. (2007). The major contributions of silicate and carbonate particles in suspended particulate matters are preferentially from dissolution of carbonate basin rock weathering. The estuary-mixing zone has the highest concentration of suspended particulate matter than river zone, which comes under (2) hypothesis reported by $\mathrm{Xu}$ and Marcantonio (2007). This signifies that the role of $\mathrm{Sr}$ in dissolved as well as in particulate forms could cause minor deviation from the conservative nature at the mixing zone by its adsorption-desorption mechanism.

\section{Conclusion}

$\mathrm{Na}, \mathrm{K}, \mathrm{Ca}, \mathrm{Mg}, \mathrm{Sr}, \mathrm{Cl}$, and $\mathrm{SO}_{4}$ concentrations in the estuarine water obtained along salinity gradients in the Changjiang river display a general two component mixing between river and seawater. The minor deviation from theoretical mixing line especially in the estuary acted a minimal non-conservative behavior. Normalized values confirmed that river contributes higher amount of all ions to coastal sea, but it substantially reduced at the estuary. This behavior may arise by suspended particles interaction and active phase change in the quantity of both organic and inorganic components. Information on such process from the river region is highly essential to predict for other zone. The $\mathrm{Sr}$ isotope mixing patterns revealed for minimal of non-conservative and deviations of all the elements do not compromise the uses of $\mathrm{Sr}$ isotopic process.

Acknowledgments This research was financially supported by the framework project of National Natural Science Foundation of China (Grant No. 90610037) and by the International Partnership Project of Chinese Academy of Sciences. The authors also particularly thanks to Dr. Yuansheng Li, Institute of Polar Research, CAS, Shanghai for providing the oceanographic instruments during sampling and also for offshore lab facility. Also thanks to Dr S. J. Kao for constructive comments for improving this manuscript. Many thanks to Dr. Pan $\mathrm{Wu}$, Dr. Houyi Zheng, Dr. Xueyan Liu for helping during sample collections.

\section{References}

Andersson PS, Wasserburg GJ, Ingri J (1992) The sources and transport of $\mathrm{Sr}$ and $\mathrm{Nd}$ isotopes in the Baltic Sea. Earth Planet Sci Lett 113:459-472

Bell RG (1994) Behavior of dissolved silica, and estuarine coastal mixing and exchange process at Tairua Harbour, New Zealand. N Z J Mar Fresh 28:55-68

Brich GF, Evenden D, Teutsch ME (1996) Dominance of point source heavy metal distributions in sediments of major Sydney estuary (Australia). Environ Geol 28:169-174

Brunskill GJ, Zagorskis I, Pfitzher J (2003) Geochemical mass balance for lithium; boron; and strontium in the Gulf of Papus; Papua New Guinea (Project TROPICS). Geochim Cosmochim Ac 67:3365-3383

Charette MA, Sholkovitz ER (2006) Trace element cycling in a subterranean estuary Part 2. Geochemistry of the pore water. Geochim Cosmochim Ac 70:811-826

Chen JS, Wang FY, Xia XH, Zhang LT (2002) Major element chemistry of the Changjiang (Yangtze River). Chem Geol 187:231-255

Ding T, Wang D, Wang C, Zhang F (2004) Silicon isotope composition of dissolved silicon and suspended matters in the Yangtze River, China. Geochim Cosmochim Ac 68:205-216

$\mathrm{Hu} \mathrm{H}, \mathrm{Hu} \mathrm{F}$ (1995) Water types and frontal surface in the Changjiang estuary. J Fish Sci China 2:81-90 (In Chinese)

$\mathrm{Hu}$ MH, Stallard RF, Edmond JM (1982) Major ion chemistry of some large Chinese rivers. Nature 298:550-553

Hunter KA (1983) On the estuarine mixing of dissolved substances in relation to colloid stability and surface properties. Geochim Cosmochim Ac 47:467-473

Ingram BL, DePaolo DJ (1993) A 4300-year strontium isotope record of estuarine paleosalinity in San Franciso Bay, California. Earth Planet Sci Lett 119:103-119

Ingram BL, Sloan D (1992) Strontium isotopic composition of estuarine sediments as paleosalinity-paleoclimate indicator. Science 255:68-72

Jiang G, Yao Y, Tang Z (2002) The analysis for influencing factor of fine sediment flocculation in the Changjiang estuary. Acta Oceanol Sin 24:51-57 (in Chinese with English abstract)

Knudsen M (1902) Berichteüber die Konstantenbestimmung zur Aufstellung hydrographischen Tabellen. Kgl Dan Vidensk Selsk Skr Naturvidensk 12:1-151

Li JY, Zhang J (2003) Variations of solid content and water chemistry at Nantong station and weathering processes of the Changjiang watershed. Resour Environ Yangtze Basin 12:363-369 (in Chinese with English abstract)

Li D, Li J, Chen J, Chen X, Chen B (2000a) A study on suspended matter in the Changiiang river estuary. Oceanol Limnol Sin 31:295-301 (in Chinese with English abstract)

Li J, He Q, Zhang C (2000b) A study on sediment deposition and resuspension in the Mouth Bar area of the Changjiang river estuary. Oceanol Limnol Sin 31(1):101-109 (in Chinese with English abstract)

Lisitsyn AP (1995) The marginal filter of the ocean. Oceanology 34:671-682

Mook WG, Koene BKS (1975) Chemistry of dissolved inorganic carbon in estuarine and coastal brackish waters. Estuar Coast Mar Sci 3:325-336

Ramanathan AL, Vaithiyanathan P, Suberamanian V, Das BK (1993) Geochemistry of the Cauvery estuary; East Coast of India. Estuaries 16:459-474 
Ray SB, Mohanti M, Somayajulu BLK (1984) Suspended matter; major cations and dissolved silicon in the estuarine water of the Mahanadi River, India. J Hydrol 69:183-196

Schijf J (2007) Alkali elements (Na; K; Rb) and alkaline earth elements $(\mathrm{Mg}$; $\mathrm{Ca}$; $\mathrm{Sr} ; \mathrm{Ba})$ in the anoxic brine of Orca Basin; north Gulf of Mexico. Chem Geol 243:255-274

Schijf J, Byrne RH (2007) Progressive dolomitization of florida limestone recorded by alkaline earth element concentrations in saline; geothermal; submarine springs. J Geo Res 12:C01003. doi:10.1029/2006JC003659

Sharma M, Balakrishna K, Hofmann AW, Shankar R (2007) The transport of osmium and strontium isotopes through a tropical estuary. Geochim Cosmochim Ac 71:4856-4867

Shi Z, Ling H (1999) Vertical profiles of fine suspension concentration in the Changjiang estuary. J Sed Res 2:59-64 (in Chinese with English abstract)

Subramanian V, Jha PK (1988) Geochemical studies on Hoogly estuary. Mitt Geol Palen Inst Scope/UNEP Sonderband, Hamburg, pp 267-288

Wang ZL, Liu CQ (2003) Distribution and partition behavior of heavy metals between dissolved and acid-soluble fractions along a salinity gradient in the Changjiang estuary, eastern China. Chem Geol 202:383-396

Wang Y, Zhang Z, Huang W Gu J (1995) Hydro-chemical Characteristics and clay minerals of suspended sediment in south Channel Changjiang estuary. Mar Sci Bull 14(4):106-113 (in Chinese with English abstract)
Wang ZL, Liu CQ, Han GL, Xu ZF (2001) Variation in Sr isotope composition of Changjiang estuarine waters: implications for water-sediment interaction. Science 44:129-133 (in Chinese)

Wang ZL, Zhang J, Liu CQ (2007) Strontium isotopic composition of dissolved and suspended loads from the main channel of the Yangtze River. Chemosphere 69:1081-1088

Xu Y, Marcantonio F (2007) Strontium isotope variation in the lower Mississippi River and its estuarine mixing Zone. Mar Chem 105:118-128

Yang SL, Zhao QY, Belkin IM (2002) Temporal variation in the sediment load of the Yangtze River and the influences of human activities. J Hydrol 263:56-71

Yang S, Jung HS, Li C (2004) Two unique weathering regimes in the Changjiang and Huanghe basins: geochemical evidence from river sediments. Sed Geol 164:19-34

Yi S, Saito Y, Zhou Q, Wang P (2003) Vegetation and climate changes in the Chang Jiang (Yangtze River) delta; China; during the past 13,000 years inferred from pollen records. Quat Sci Rev 22:1501-1519

Zhang J, Huang WW, Liu MG, Zhou Q (1990) Drainage basin weathering and major element transportation of two large Chinese rivers Huanghe and Changjiang. J Geo Res 95:13277-13288

Zhang J, Huang WW, Letolle R, Jusserand C (1995) Major element chemistry of the Huanghe (Yellow River); China-weathering processes and chemical fluxes. J Hydrol 168:173-203

Zhou H (1994) Features of turbidity maximum in Yangtze River estuary. J Chongqing Jiaotong Inst 13:8-15 (in Chinese with English abstract) 